\title{
Engineering of a Novel Ruthenium Sensitizer and its Application in Dye-Sensitized Solar Cells for Conversion of Sunlight into Electricity C. Klein ${ }^{\mathrm{a}}$, Md. K. Nazeeruddin ${ }^{\mathrm{a}}$, P. Liska ${ }^{\mathrm{a}}$, Davide Di Censo ${ }^{\mathrm{a}}$, N. Hirata ${ }^{\mathrm{b}}$, E. Palomares $^{\mathrm{b}, \mathrm{c}}$, J.R.Durrant ${ }^{\mathrm{b}}$ and M. Grätzel ${ }^{\mathrm{a}}$
}

\section{Supporting Information}

\section{Experimental}

All reagents puriss grade quality were purchased from Fluka except dichloro(pcymene)ruthenium(II) dimer from Aldrich and were used without further purifications. The intermediate product $4,4^{\prime}$-diformyl-2,2'bipyridine was synthesized according to literature procedures. ${ }^{1}$ THF and Toluene were distilled over sodium and under argon. ${ }^{1} \mathrm{H}$ and ${ }^{13} \mathrm{C}-\mathrm{NMR}$ spectra were recorded with a Brüker AM-200 (200 MHz) spectrometer at 298K with TMS as internal standard. The FTIR spectra were measured using a Digilab 7000 FTIR spectrometer. The ATR data reported here was taken with the 'Golden Gate' diamond anvil ATR accessory (Graseby-Specac) using typically 64 scans at a resolution of $2 \mathrm{~cm}^{-1} . \mathrm{UV} / \mathrm{V}$ is and fluorescence spectra were recorded in $1 \mathrm{~cm}$ path length quartz cell on a Cary 5 spectrophotometer and Spex Fluorolog 112 Spectroflurimeter, respectively. Electrochemical data were obtained by cyclic and square wave voltammetry in a conventional three-electrode cell using a AUTOLAB system. A glassy-carbon or a gold working electrode, glassy-carbon auxiliary electrode and silver rod used as a quasi reference electrode in a single-compartment-cell configuration. Cyclic voltammogram of K8 complex was obtained by dissolving $1 \mathrm{mM}$ of each complex in DMF containing 0.1 
M tetrabutylammonium perchlorate salt. After the end of measurement, ferrocene cyclic voltammogram was recorded by adding at the end of the experiment and the reported potentials were against ferrocene/ferricenium couple.

The K8 sensitizer solutions of $3 \times 10^{-4} \mathrm{M}$ were prepared in 1:1 acetonitrile and tert-butanol solution. The heated $\mathrm{TiO}_{2}$ electrodes were dipped into dye solution for 18 hours. The dye-coated electrodes were rinsed quickly with acetonitrile and used as such for photovoltaic measurements. The platinum coated counter electrode was prepared using NSG 10 conducting glass with chemically deposited platinum from $0.05 \mathrm{M}$ hexachloroplatinic acid. The dye coated $\mathrm{TiO}_{2}$ film and the platinum coated counter electrode were put together with a thin transparent film of polymer gasket frame (DuPont, Bynel). The sandwiched electrodes were tightly held and then heat was applied around the polymer frame to seal the two electrodes. A thin layer of electrolyte was introduced into inter electrode space from the counter electrode side through a pre-drilled hole. The drilled hole was sealed with microscope cover slide and Bynel to avoid leakage of the electrolyte solution. The electrolyte composition was $0.6 \mathrm{M}$ M-methyl-N-butyl imidiazolium iodide, 0.05 M iodine, 0.05 M LiI and 0.5 M tert.butylpyridine in 50/50 (v/v) mixture of valeronitrile and acetonitrile.

\section{Synthesis}

\section{4,4'-bis(E-methoxycarbonylvinyl)-2,2'-bipyridine}
A mixture of 4,4'-diformyl-2,2'bipyridine ${ }^{1}(0.5 \mathrm{~g}, 2.4 \mathrm{mmol})$ and methoxycarbonylmethylene-triphenylphosphorane $(1.9 \mathrm{~g}, 5.6 \mathrm{mmol})$ in $50 \mathrm{ml}$ of dry toluene was refluxed for $18 \mathrm{~h}$. The resulting solution was let stand in the fridge for 2 hours before being filtered. The resulting crystalline solid was respectively washed with cold 
toluene $(2 \times 5 \mathrm{ml})$ and cold acetone $(2 \times 5 \mathrm{ml})$ to afford $0.6 \mathrm{~g}(78 \%)$ of pure $4,4^{\prime}$ bis(methoxycarbonylvinyl)-2,2'-bipyridine as a slightly brown crystalline solid.

Anal. found: C, 65.99; $\mathrm{H}, 4.86 ; \mathrm{N}, 8.93 \%$. Calcd. for $\mathrm{C}_{18} \mathrm{H}_{16} \mathrm{~N}_{2} \mathrm{O}_{4}$ : C, 66.66; H, 4.97; N, $8.64 \%$.

${ }^{1} \mathrm{H}-\mathrm{NMR}\left(\mathrm{CDCl}_{3}, 298 \mathrm{~K}, 200 \mathrm{MHz}, \delta\right.$ in ppm) 3.85 (s, 6H), $6.75(\mathrm{~d}, J=16 \mathrm{~Hz}, 2 \mathrm{H}), 7.41$ (dd, $J=5 \times 1.5 \mathrm{~Hz}, 2 \mathrm{H}), 7.72(\mathrm{~d}, J=16 \mathrm{~Hz}, 2 \mathrm{H}), 8.56(\mathrm{~s}, 2 \mathrm{H}), 8.74(\mathrm{~d}, J=5 \mathrm{~Hz}, 2 \mathrm{H})$.

${ }^{13} \mathrm{C}-\mathrm{NMR}\left(\mathrm{CDCl}_{3}, 298 \mathrm{~K}, 50 \mathrm{MHz}, \delta\right.$ in ppm) 52.0, 119.3, 122.2, 122.7, 142.0, 142.7, $150.0,156.4,166.52$.

\section{4,4'-bis(E-carboxyvinyl)-2,2'-bipyridine}

To a solution of 4,4'-bis( $E$-methoxycarbonylvinyl)-2,2'-bipyridine $(0.5 \mathrm{~g}, 1.5 \mathrm{mmol})$ in $50 \mathrm{ml}$ of THF was added LiOH. $\mathrm{H}_{2} \mathrm{O}(0.65 \mathrm{~g}, 15 \mathrm{mmol})$ dissolved in $5 \mathrm{ml}$ of $\mathrm{H}_{2} \mathrm{O}$. The resulting mixture was heated to reflux for $5 \mathrm{~h}$. After being cooled to room temperature, $\mathrm{pH}$ was adjusted to 2 with conc. $\mathrm{HCl}$. The resulting precipitate was filtered off and successively washed with $\mathrm{H}_{2} \mathrm{O}$, acetone and $\mathrm{Et}_{2} \mathrm{O}$ to afford $0.44 \mathrm{~g}(97 \%)$ of pure 4,4'$\operatorname{bis}(E$-carboxyvinyl)-2,2'-bipyridine as a slightly pink solid. Due to the low solubility of the 4,4'-bis(E-carboxyvinyl)-2,2'-bipyridine, its ${ }^{1} \mathrm{H}$ and ${ }^{13} \mathrm{C}$ NMR characterizations were performed on its bis-triethylammonium salt.

Anal. found: $\mathrm{C}, 61.3 ; \mathrm{H}, 4.26 ; \mathrm{N}, 8.37 \%$. Calcd. for $\mathrm{C}_{16} \mathrm{H}_{12} \mathrm{~N}_{2} \mathrm{O}_{4} \cdot \mathrm{H}_{2} \mathrm{O}: \mathrm{C}, 61.15 ; \mathrm{H}, 4.48$; N, $8.91 \%$.

${ }^{1} \mathrm{H}-\mathrm{NMR}$ (DMSO-d $/ \mathrm{D}_{2} \mathrm{O}: 85 / 15,298 \mathrm{~K}, 200 \mathrm{MHz}, \delta$ in ppm) $6.66(\mathrm{~d}, J=16 \mathrm{~Hz}, 2 \mathrm{H})$, $7.18(\mathrm{~d}, J=16 \mathrm{~Hz}, 2 \mathrm{H}), 7.56(\mathrm{~d}, J=5 \mathrm{~Hz}, 2 \mathrm{H}), 8.33(\mathrm{~s}, 2 \mathrm{H}), 8.62(\mathrm{~d}, J=5 \mathrm{~Hz}, 2 \mathrm{H})$.

${ }^{13} \mathrm{C}-\mathrm{NMR}$ (DMSO-d $/ \mathrm{D}_{2} \mathrm{O}: 85 / 15,298 \mathrm{~K}, 50 \mathrm{MHz}, \delta$ in ppm) 118.9, 122.3, 133.4, 134.6, $145.3,150.2,155.7,170.7$. 


\section{Synthesis of $\left[\mathrm{Ru}(\mathrm{II}) \mathrm{L}_{2}(\mathrm{NCS})_{2}\right]$, K8 complex}

A mixture of 4,4'-bis(E-carboxyvinyl)-2,2'-bipyridine (100 $\mathrm{mg}, 0.34 \mathrm{mmol})$ and dichloro( $p$-cymene)ruthenium(II) dimer $(50 \mathrm{mg}, 0.081 \mathrm{mmol})$ in dry and argon degassed DMF $(25 \mathrm{ml})$ was heated to $150^{\circ} \mathrm{C}$ for $4 \mathrm{~h}$. To the dark green solution was added $\mathrm{NH}_{4} \mathrm{NCS}(390 \mathrm{mg}, 5.1 \mathrm{mmol})$ and the mixture was heated to $150^{\circ} \mathrm{C}$ for $4 \mathrm{~h}$ more. After evaporation of the DMF, the purple residue was suspended in water $(150 \mathrm{ml})$ and sonicated for $5 \mathrm{~min}$. The $\mathrm{pH}$ was adjusted to 3 with $\mathrm{HNO}_{3} 0.2 \mathrm{M}$ and the mixture was let stand in the fridge overnight. The resulting purple solid was filtered, washed with water and $\mathrm{Et}_{2} \mathrm{O}$. Purification on Sephadex LH20 afforded the desired complex as a dark purple solid.

Analysis calculated for $\mathrm{C}_{34} \mathrm{H}_{24} \mathrm{~N}_{6} \mathrm{O}_{8} \mathrm{RuS}_{2}: \mathrm{C}, 50.43 \% ; \mathrm{H}, 2.99 \% ; \mathrm{N}, 10.38 \%$. Found: $\mathrm{C}$, $50.02 \% ; \mathrm{H}, 3.38 \% ; \mathrm{N}, 10.42 \%$.

${ }^{1} \mathrm{H}$ NMR $\left(\delta_{\mathrm{H}} / \mathrm{ppm}\right.$ in $\left.\mathrm{CH}_{3} \mathrm{OH}-\mathrm{D}_{4}, J \mathrm{~Hz}\right): 9.21\left(\mathrm{~d}, \mathrm{H}^{6,5}, J 5.9\right) ; 9.15\left(\mathrm{~s}, \mathrm{H}^{3}\right) ; 8.99 .\left(\mathrm{s}, \mathrm{H}^{3^{\prime}}\right)$; $8.21\left(\mathrm{dd}, \mathrm{H}^{5,6,3}, J\right.$ 5.9;1); 7.8 (d, vinyl-H, $J$ 15.94); 7.62 (d, $\mathrm{H}^{6,5^{\prime}}, J$ 5.9); 7.55 (d, vinyl-H, $J$ 15.97); 7.45 (dd, $\mathrm{H}^{5^{\prime}, 6^{\prime} 3^{\prime}}, J$ 5.9;1); 7.21 (d, vinyl-H, $J$ 16.04); 6.99 (d, vinyl-H, $J$ 16.04) ${ }^{1} \mathrm{H}$ NMR $\left(\delta_{\mathrm{H}} / \mathrm{ppm}\right.$ in DMSO-D $\left.6, J \mathrm{~Hz}\right): 9.43\left(\mathrm{~d}, \mathrm{H}^{6,5}, J 5.9\right) ; 8.86\left(\mathrm{~s}, \mathrm{H}^{3}\right) ; 8.71 .\left(\mathrm{s}, \mathrm{H}^{3^{\prime}}\right)$; $7.98\left(\mathrm{dd}, \mathrm{H}^{5,6,3}, J 5.9 ; 1\right) ; 7.65\left(\mathrm{~d}, \mathrm{H}^{6^{\prime}, 5^{\prime}}, J\right.$ 6); 7.62 (d, vinyl-H, $\left.J 15.94\right) ; 7.45\left(\mathrm{dd}, \mathrm{H}^{5^{\prime}, 6^{\prime} 3^{\prime}}, J\right.$ 5.9;1); 7.38 (d, vinyl-H, $J$ 16.05); 7.11 (d, vinyl-H, $J$ 16.05); 6.86 (d, vinyl-H, $J$ 15.94).

${ }^{13} \mathrm{C}$ NMR $200 \mathrm{MHz}$, (DMSO-D6) $\delta$ ppm: $167.59\left(\mathrm{C}^{9}\right) ; 167.53\left(\mathrm{C}^{9}\right) ; 158.88\left(\mathrm{C}^{6}\right) ; 157.83$ $\left(C^{6^{\prime}}\right) ; 152.66\left(C^{2}\right) ; 152.38\left(C^{2}\right) ; 142.93\left(C^{4}\right) ; 142.43\left(C^{4}\right) ; 138.51\left(C^{8}\right) ; 137.66\left(C^{8}\right)$; 134.4 (C of NCS); $128.88\left(\mathrm{C}^{7}\right) ; 128.17\left(\mathrm{C}^{7}\right) ; 125.93\left(\mathrm{C}^{3}\right) ; 125.93\left(\mathrm{C}^{3}\right) ; 121.39\left(\mathrm{C}^{5}\right)$; $121.07\left(C^{5}\right)$. 


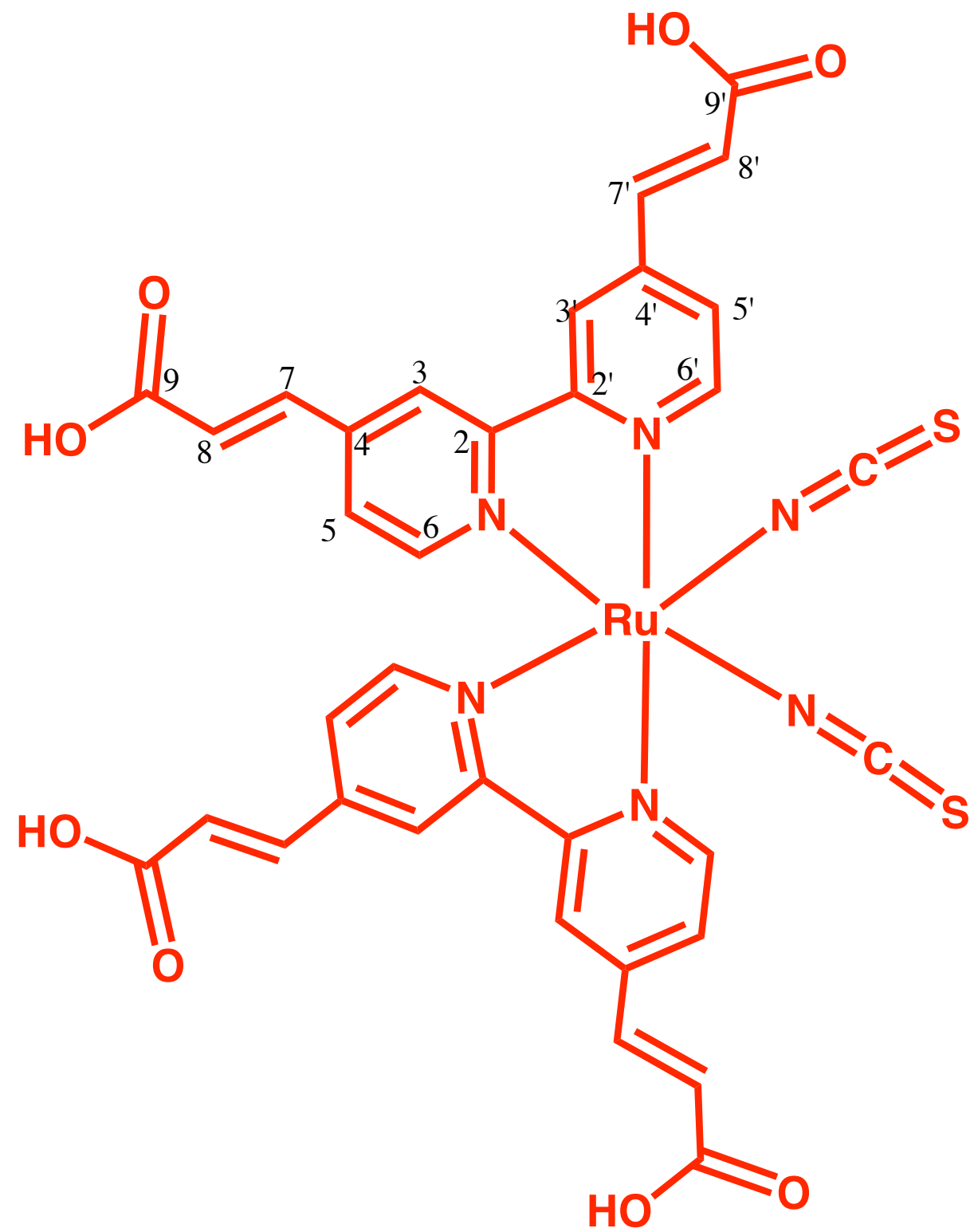

Figure 1S. Chemical structure of K8 complex with numbering scheme. 


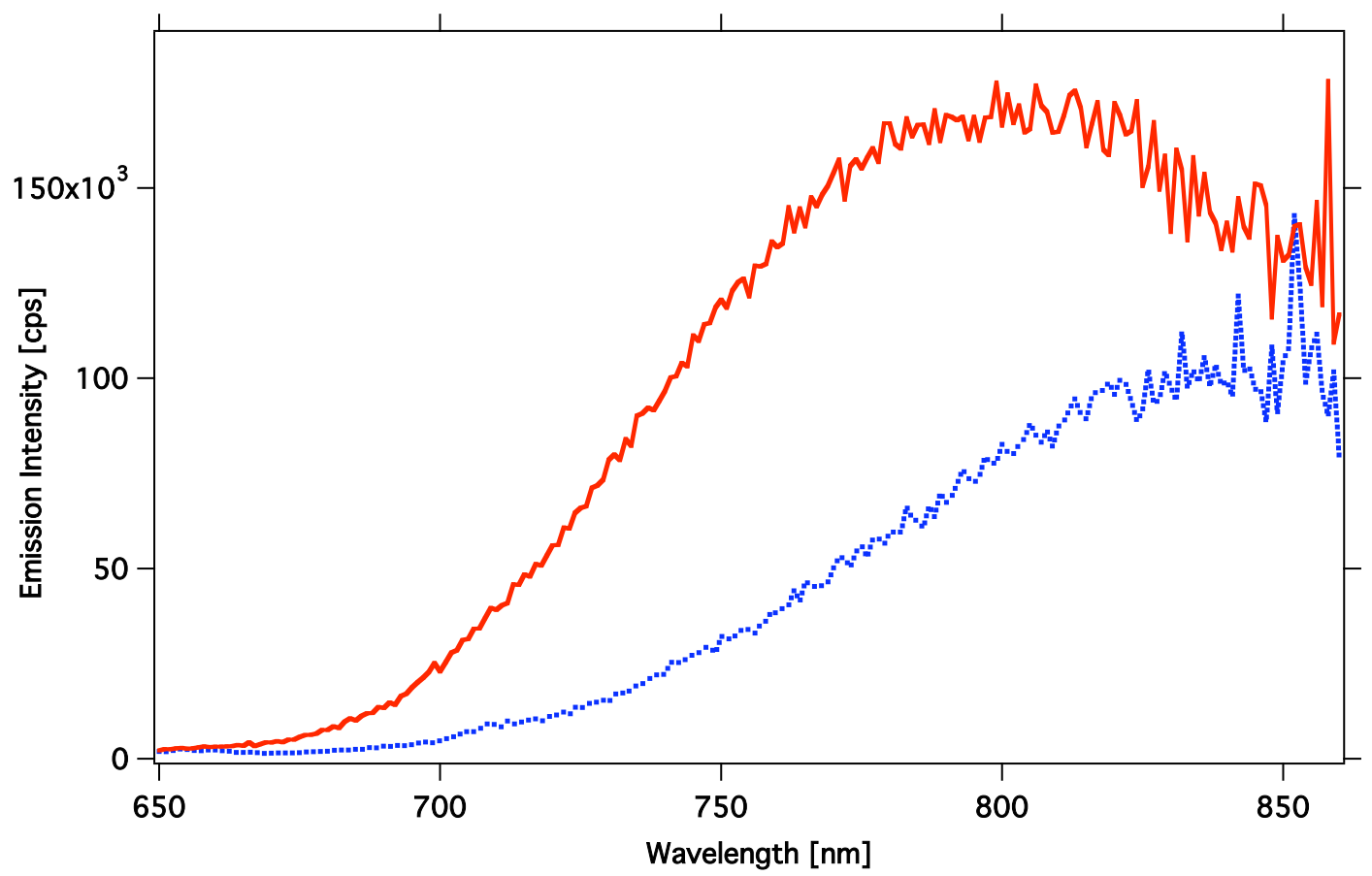

Figure 2S. Emission spectra of N3 (red line) and K8 (blue broken line) complexes obtained in DMF solution by exciting at $550 \mathrm{~nm}$ and at $298 \mathrm{~K}$.

\section{References}

(1) P. Dupau, T. Renouard, H. Le Bozec, Tetrahedron Lett., 1996, 37 (42), 7503 7506. 